\title{
SURFACE MOISTURE AND IRRIGATION MAPPING AT AGRICULTURAL FIELD SCALE USING THE SYNERGY SENTINEL-1/SENTINEL-2 DATA
}

\author{
M. Zribi ${ }^{1,{ }^{*}}$, N. Baghdadi ${ }^{2}$, S. Bousbih ${ }^{1,3}$, M. El-Hajj ${ }^{2}$, Q. Gao ${ }^{1,4,5}$ \\ ${ }^{1}$ CESBIO, 18, Avenue Edouard Belin, 31401 Toulouse, France-mehrez.zribi@cesbio.cnes.fr \\ ${ }^{2}$ TETIS, University of Montpellier, 34093 Montpellier CEDEX 5, France - Nicolas.baghdadi@teledetection.fr \\ ${ }^{3}$ Université de Carthage/INAT/LR GREEN-TEAM, 43 Avenue Charles Nicolle, Tunis 1082, Tunisia - safa.bousbih@cesbio.cnes.fr \\ ${ }^{4}$ ISARDSAT, Parc Tecnològic Barcelona Activa, Carrer de Marie Curie, 8, 08042 Barcelona, Spain \\ ${ }^{5}$ Observatori de l'Ebre (OE), Ramon Llull University, 43520 Roquetes, Spain
}

Commission III, WG III/10

KEY WORDS: Radar, Sentinel-1, Sentinel-2, Soil moisture, Irrigation mapping, Inversion

\begin{abstract}
:
Soil moisture plays a key role in various processes at the soil-vegetation-atmosphere interface, such as evapotranspiration, infiltration and runoff. In this study, we firstly propose a global analysis of Sentinel-1 (S1) \& Sentinel-2 (S2) data potential to retrieve soil moisture. Two approaches are tested. The first one is based on neural network approach; it uses Integral Equation Model (IEM) coupled to Water Cloud Model for vegetation cover backscattering simulation (El Hajj et al., 2017). The second approach considers change detection methodology. It estimates change of soil moisture with the driest and highest moisture levels, and also change of moisture between successive radar acquisitions (Gao et al., 2017). The proposed approaches are validated over three agricultural regions, south of France, Urgell (Spain) and Merguellil (Tunisia). In these different sites, important ground campaigns have been realized over reference fields with different types of measurements (soil moisture and roughness, Leaf area Index of vegetation cover). The retrieved accuracy of estimated volumetric soil moisture is about 5 vol.\%. Based on estimated moisture products, two methodologies are considered to map irrigated areas (Gao et al., 2018, Bousbih et al., 2018). An analysis of different metrics (mean, variance, correlation length, etc.) of radar signal time series and surface parameters (moisture and NDVI) are tested. The proposed classification of irrigated areas is based on a combination of Support Vector Machine (SVM) and decision tree methodologies. For Urgell and Merguellil sites, a mapping of irrigated fields is proposed. The accuracy of mapping is higher than $75 \%$ for the two studied sites.
\end{abstract}

\section{INTRODUCTION}

The soil moisture plays an essential role in different transfers between continental surfaces and the atmosphere. It has a key role in the distribution of rainwater between different processes (infiltration, runoff and evapotranspiration). This soil property is particularly important in the context of semi-arid areas where irrigation may be essential for agriculture. Soil moisture conditions guide managers in irrigation choices.

Soil water content is often measured by instruments at a local point scale. These are especially measurements made by thetaprobes or TDR. These measures do not allow spatialization essential for the managers and also the scientists interested in agriculture, hydrology or meteorology. In this context, for more than twenty years, remote sensing has shown great potential to estimate the properties of agricultural surfaces and particularly the soil water content. Microwave remote sensing has shown the greatest potential for estimating soil moisture. For several years, passive microwave radiometers have shown a high accuracy of this estimate with RMS errors close to 4-5\% (Zribi et al., 2011a). SMOS and SMAP sensors are currently in orbit and provide near-daily estimates of soil moisture. The difficulty with these sensors is the limitation of their spatial resolution which is of several kilometers, which can be a real brake to the use a local scale, like that of the agricultural fields.

Simultaneously with these developments, Synthetic Aperture Radar (SAR) technique has shown for over twenty years a high potential to estimate the water content at high spatial resolution (Tomer et al., 2015, Gorrab et al., 2015, El Hajj et al., 2016). During the 2000s, several sensors are launched (ASAR, TERRASAR-X...). They have allowed several developments of algorithms to restore the water content condition and soil roughness. Backscatter models were developed, essentially physical such as AIEM or semi-empirical (Fung et al., 1992). These models made it possible to understand the physics of radar scattering before switching to inversion step. Concerning the estimation of the soil water content, the proposed approaches are numerous, they are empirical approaches based on one or more radar configurations (incidences, polarizations), approaches based on the inversion of physical or semiempirical (Fung et al., 1992, Oh et al., 1992), approaches using neural networks or methods based on change detection (El Hajj et al., 2017). The estimation of soil moisture is generally with an accuracy of about $4-6 \%$. In the case of soils with vegetation cover, the Water Cloud Model (Attema et al., 1978) is frequently used to model the radar signal with a first soil scattering component and a second vegetation scattering component. In order to characterize the vegetation cover, there is an increasing tendency to go through an optical / radar synergy. The vegetation cover parameters (Prévot et al., 1993) are retrieved through different satellite indices (NDVI, LAI, etc.).

In this context, there have also been several methods developed for mapping irrigated areas (Thenkabail et al., 2004, Gumma et

\footnotetext{
* Corresponding author
} 
al., 2011, Fieuzal et al., 2011). The most used methods are based on one optical image or optical time series. The irrigation indicator is often linked to the development of vegetation cover. In this article, we first explain different approaches used to estimate soil moisture content using S1 and S2 data. There are two methods, one based on neural networks, one using change detection. The soil moisture estimates are validated on different study sites (southern France, Merguellil and Urgell). Two approaches to mapping irrigation are then proposed. The first one is based on the analysis of the S1 radar data series. The second uses moisture products estimated from S1 \& S2 data.

\section{STUDIED SITES ET DATABASE}

\subsection{Studied sites}

The first site is Merguellil site located on the plain of Kairouan (Zribi et al., 2011b), located in the center of Tunisia. This region is characterized by a semi-arid climate with $300 \mathrm{~mm}$ of annual precipitation. The site is agricultural, with mainly annual crops (wheat, barley, vegetables) and olive groves.

The second site of $20 \mathrm{~km}$ by $20 \mathrm{~km}$ is identified on the basin of Urgell in Spain (Gao et al., 2017). It is a semi-arid site with annual rainfall of $370 \mathrm{~mm}$. It is an agricultural site with a strong presence of irrigation.

Soil property measurements are carried out on the different study sites. This is particularly the point soil moisture measured simultaneously to the passage of the satellite S1 for different reference fields. These data are used to calibrate and validate the algorithms proposed in this study.

The third site is a flat area located in the south west of France. The climate of the study site is Mediterranean with a rainy season between mid-October and March and an average cumulative rainfall of approximately $750 \mathrm{~mm}$. The average air temperature varies between $3{ }^{\circ} \mathrm{C}$ and $29^{\circ} \mathrm{C}$. The study site is composed mainly of forest, vineyard, grassland, maize, and wheat.

\subsection{Satellite data}

Sentienl-1A and Sentinel-1B images were acquired between December 2015 and March 2017. The two satellites are in the same orbit. They operate in C-band $(5.4 \mathrm{GHz})$ and Interferometric Wideswath (IW) mode, with a spatial resolution of $10 \mathrm{~m}$. Each satellite has a revisit time of 12 days, which implies a final revisit time equal to six days. The sensors provide dual-polarization imagery ( $\mathrm{VV}$ and $\mathrm{VH})$ at an incidence angle ranged between $39^{\circ}$ and $40^{\circ}$. We used Level-1 Ground range detection (GRD) products that consist of focused SAR that has been detected, multi-looked and projected to groundrange using an Earth Ellipsoid Model.

The image processing was executed using the Toolbox in the Sentinel Application Platform (SNAP). The first step was to convert the signal in order to obtain the backscattering coefficient. A terrain correction was then applied to correct geometric distortions using a Digital Elevation Model (DEM), more precisely those proposed by the SRTM (Shuttle Radar Topography Mission) at $30 \mathrm{~m}$ spatial resolution. Finally, thermal noise removal and a Lee filter were applied to reduce the speckle effect. The backscattering coefficient was averaged for each reference field.

Optical images were obtained from the Sentinel-2A satellite on dates close to Sentinel-1 images acquired from December 2015 to March 2017. The S-2A images were downloaded and processed from THEIA, a French open-source land data service center website (https://www.theia-land.fr/).

The data were derived from cloud-free images with radiometric and atmospheric corrections. The Normalized Difference
Vegetation Index (NDVI) was then computed, using Band 4 and Band 8, which represent the Red Reflectance (RED) and the Near-Infrared Reflectance (NIR), expressed by:

$$
N D V I=(\mathrm{NIR}-\mathrm{RED}) /(\mathrm{NIR}+\mathrm{RED})
$$

The NDVI values were averaged for each reference field to characterize the vegetation.

\section{SOIL MOISTURE ESTIMATION}

\subsection{Radar signal modeling}

The Water Cloud Model (Attema et al., 1978) was developed in order to simulate the radar signal when it is backscattered and affected by the soil surface moisture and the plant canopies. The total backscattering coefficient $\left(\sigma^{0}\right)$ in this model is given by the following expressions:

$$
\begin{gathered}
\sigma^{0}=\sigma_{v e}^{0}+\sigma_{v e g / \text { soil }}^{0}+\tau^{2} \\
\tau^{2}=\exp (-2 B V \sec (\theta))
\end{gathered}
$$

Vegetation backscattering is modeled as:

$$
\sigma_{v e g}^{0}=A V \cos (\theta)\left(1-\tau^{2}\right)
$$

Soil backscattering is modeled by IEM model or by a linear model as:

$$
\sigma_{\text {soil }}^{0}=C \cdot 10^{D \cdot m v}
$$

Which is taken to be a linear relationship between soil moisture and radar signal in $\mathrm{dB}$ scale, with parameters $\mathrm{C}$ and $\mathrm{D}$ to calibrate. $\tau^{2}$ is the two-way vegetation transmissivity, $m v$ is the soil moisture, $\theta$ the incidence angle and $\mathrm{V}$ the vegetation parameter. The $\sigma^{0}{ }_{\text {veg/soil }}$ is related to multiple scattering effects, which can often be neglected in the case of wheat scattering.This model was calibrated using ground measurements from different studied sites and satellite data (radar and optical data).

Two approaches are then considered to retrieve soil moisture: Neural network and change detection.

\subsection{Neural network}

Our first approach for soil moisture estimates uses the neural networks technique to invert the radar signal and estimate the soil moisture (Paloscia et al., 2013, El Hajj et al., 2017). First, a parameterized Water Cloud Model combined with the Integral Equation Model (IEM) were used to generate a synthetic database of the backscattering coefficient in the polarizations $\mathrm{VV}$ and $\mathrm{VH}$ (incidence angle between $20^{\circ}$ and $45^{\circ}$ ) for a wide range of soil moisture $(2<m v($ vol. $\%)<40)$, soil roughness $(0.5$ $<$ Hrms $(\mathrm{cm})<3.8)$, and vegetation conditions $(0<$ NDVI $<0.75$ ). Second, a gaussian noise is added to synthetic database to obtain more realistic data. These databases were divided in two sets, a first one to train the neural network, a second one to validate the trained neural network. Finally, the trained neural network is applied to the real database to estimate soil moisture. The retrieved soil moisture RMS errors are about $5 \%$. The figure 1 below shows a map of soil moisture in the Occitanie region (southern France). 


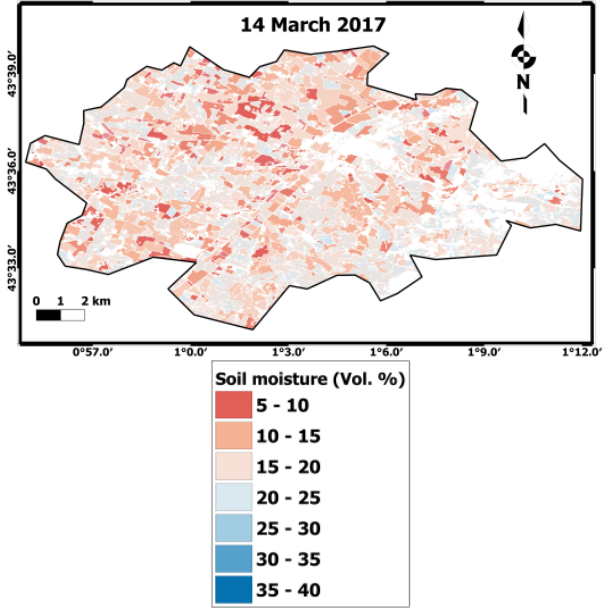

Figure 1. Retrieval of soil moisture over Occitanie region (France)

\subsection{Change detection approach}

Temporal variations in soil moisture can be directly related to the dynamics of the radar signal. When radar signals are considered for the same $100 \times 100 \mathrm{~m}$ cell, and for approximately the same NDVI index, the roughness effect can be considerably reduced by computing the difference between two radar signals recorded at two dates (Gao et al., 2017).

For a given NDVI (retrieved from S2 data), by taking all of the corresponding radar data into account, the minimum value of $\sigma^{\circ}$, corresponding to the driest signal, can be determined for each cell. The radar signal difference for a given cell $(\mathrm{i}, \mathrm{j})$, between one radar signal at date $\mathrm{d}$ and the driest signal, can be written as follows:

$$
\begin{array}{r}
\Delta \sigma_{(i, j)}^{N D V I}=\sigma_{(i, j), N D V I}^{0}(d)-\sigma_{d r y,(i, j), N D V I}^{0} \\
=H_{(i, j)}(N D V I, M v)
\end{array}
$$

where $\sigma_{(i, j), N D V I}^{0}(d)$ is the backscattered signal from cell $(\mathrm{i}, \mathrm{j})$ at date $\mathrm{d}$, with the corresponding NDVI computed from the (S2) optical images;

$\sigma_{d r y,(i, j), N D V I}^{0}$ is the lowest backscattered signal, corresponding to the driest conditions, and computed using the S1 time-series using the same NDVI as for the data recorded on date $\mathrm{d}$ $\left(\sigma_{(i, j), N D V I}^{0}(d)\right)$, and $H_{(i, j)}(N D V I, M v)$ is a function of the NDVI and soil moisture $M v$ in cell (i,j).

Radar signal change is modeled as a function of moisture change and NDVI. With the increasing of vegetation cover, the radar signal change due to soil moisture decreases. A relationship is established between radar signal change and soil moisture for NDVI between 0 and 0.7 . The proposed approach is validated with ground measurements carried out in two demonstration fields in Urgell site (Spain). The estimated (volumetric) RMS soil moisture errors is approximately 8.7 vol.\%. Figure 2 illustrates a mapping of soil moisture with this approach over Urgell site.

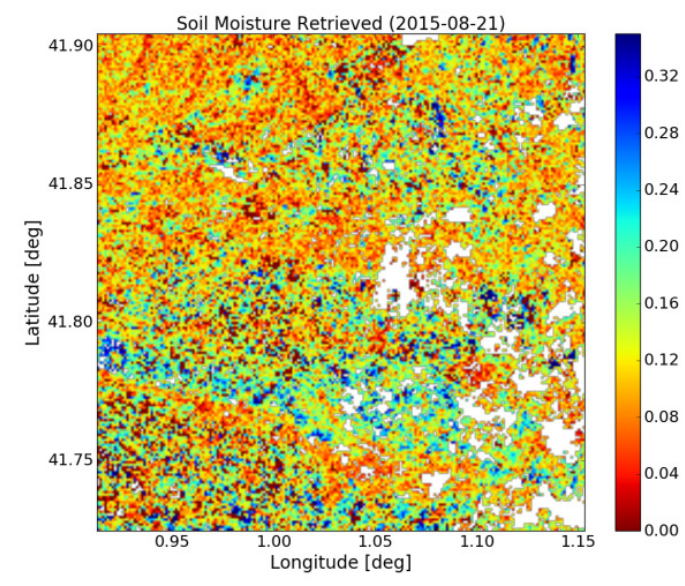

Figure 2. Retrieved soil moisture map obtained using change detection approach over Urgell site (Spain).

\section{IRRIGATION MAPPING}

Two approaches are considered to map irrigation, a first one considering S1 time series and a second considers output of satellite products from $\mathrm{S} 1 \& \mathrm{~S} 2$.

\subsection{Approach based on S1 time series}

Over a period of two years, the S1 time series are analyzed (Gao et al., 2018). The mean of the radar signals, its variance and the temporal correlation length are estimated from the radar time series. These indicators are used to separate irrigated and nonirrigated classes. Three classes are identified. The results show a very good accuracy of $81 \%$ using the SVM approach (Figure 3). The average radar signal is the best indicator for separating irrigated areas from non-irrigated areas. Variance and correlation length are considered to separate irrigated trees and irrigated annual crops. Validations of the classification are based on the SIGPAC database over 26,434 fields in the whole study area. The use of Random forest approach gives the same results as for SVM.

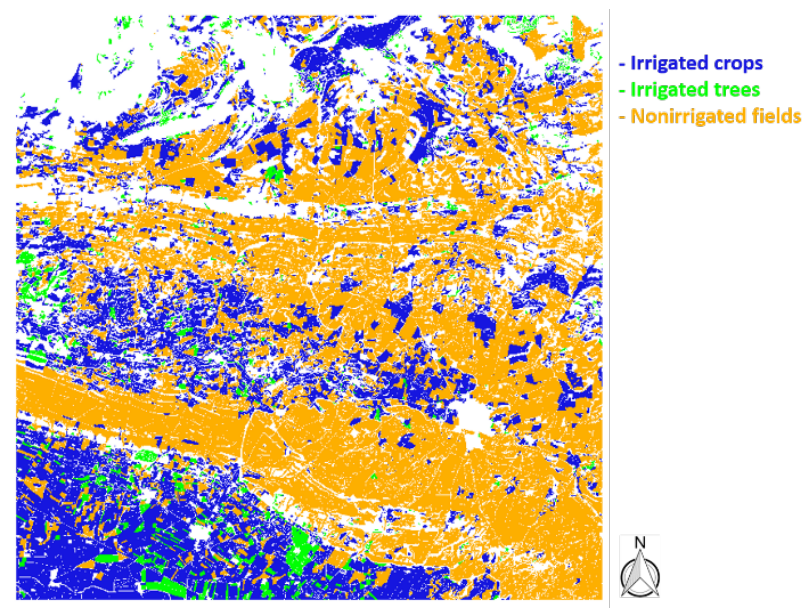

Figure 3. Mapping of irrigated areas

\subsection{Approach based on satellite products}

The classification process was used to discriminate between irrigated and non-irrigated fields. Two classifications were used 
(Bousbih et al., 2018). The first one concerns the SVM classification to delineate between the irrigated and rainfed agricultural fields, using the means and variance soil moisture time series. The second one uses the Decision Tree classification to produce the irrigation map over the study site (the Kairouan plain). Areas including water and salt bodies, reliefs, urban areas are masked out, only agricultural areas were considered.

Figure 4 provides the irrigation map derived from the soil moisture estimation, using the mean and variance times series from January to March, corresponding to the period of maximum vegetation growth. Validation involves the use of confusion matrix, which compares the classified fields to the reference fields. The results provide an overall accuracy about $77 \%$. The results showed that the soil moisture is a reliable indicator for irrigation detection, particularly in semi-arid area.

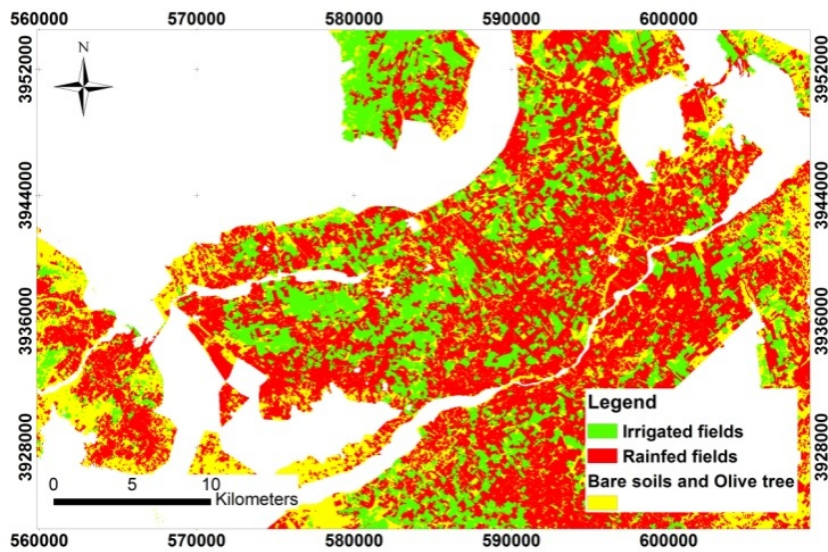

Figure 4. Irrigation map using soil moisture parameters for irrigated and non-irrigated areas.

\section{ACKNOWLEDGEMENTS}

This research was supported by the French Space Study Center (CNES, DAR 2018 TOSCA). The authors wish to thank the European Commission and the European Space Agency (ESA) for kindly providing the Sentinel-1 images. We used Copernicus Sentinel-2 data processed to level $2 \mathrm{~A}$ by the French land data service center (Theia: https://www.theia-land.fr). The authors wish to thank technical teams of CESBIO, IRSTEA, IRD and INAT for ground measurements.

\section{REFERENCES}

Attema, E.P.W. and Ulaby, F.T. 1978. Vegetation modeled as a water cloud. Radio Sci., 13, pp. 357-364.

Baghdadi, N., Choker, M., Zribi, M., El-hajj, M., Paloscia, S., Verhoest, N., Lievens, H., Baup, F., and Mattia, F. 2016. A new empirical model for radar scattering from bare soil surfaces. Remote Sens., 8, 920, DOI: 10.3390/rs8110920.

Bousbih, S., Zribi, M., Lili-Chabaane, Z., Baghdadi, N., El Hajj, M., Gao, Q., and Mougenot, B. 2017. Potential of Sentinel-1 Radar Data for the Assessment of Soil and Cereal Cover Parameters. Sensors, 17, 2617, DOI: 10.3390/s17112617.

Bousbih, S., Zribi, M., El Hajj, M., Baghdadi, N., LiliChabaane, Z., Gao, Q., and Fanise, P. 2018. Soil moisture and irrigation mapping in a semi-arid region based on Sentinel-1 and Sentinel-2 synergy, Remote Sensing, 10(12), 1953.

El Hajj, M., Baghdadi, N., Zribi, M., Belaud, G., Cheviron, B., Courault, D., and Charron, F. 2016. Soil moisture retrieval over irrigated grassland using X-band SAR data. Remote Sens. Environ., 176, pp. 202-218.

El Hajj, M., Baghdadi, N., Zribi, M., and Bazzi, H. 2017. Synergic use of Sentinel-1 and Sentinel-2 images for operational soil moisture mapping at high spatial resolution over agricultural areas. Remote Sens., 9, 1292, DOI: $10.3390 /$ rs9121292.

Fieuzal, R., Duchemin, B., Jarlan, L., Zribi, M., Baup, F., Merlin, O., Dedieu, G., Garatuza-Payan, J., Watt, C., and Chehbouni, A. 2011. Combined use of optical and radar satellite data for the monitoring of irrigation and soil moisture of wheat crops. Hydrol. Earth Syst. Sci., 15, 1117-1129.

Fung, A.K., Li, Z., and Chen, K.S. 1992. Backscattering from a randomly rough dielectric surface. IEEE Trans. Geosci. Remote Sens., 30, 356-369.

Gao, Q., Zribi, M., Baghdadi, N., and Escorihuela, M.J. 2017. Synergetic Use of Sentinel-1 and Sentinel-2 Data for Soil Moisture Mapping at $100 \mathrm{~m}$ Resolution. Sensors, 17, 1966, DOI: $10.3390 / \mathrm{s} 17091966$.

Gao, Q., Zribi, M., Escorihuela, M., Baghdadi, N., and Segui, P. 2018. Irrigation Mapping Using Sentinel-1 Time Series at Field Scale. Remote Sens., 10, 9, 1495.

Gorrab, A., Zribi, M., Baghdadi, N., Mougenot, B., Fanise, P., Lili Chabaane, Z. 2015. Retrieval of Both Soil Moisture and Texture Using TerraSAR-X Images. Remote Sens., 7, 1009810116, DOI: $10.3390 /$ rs 70810098 .

Gumma, M.K., Thenkabail, P.S., Hideto, F., Nelson, A., Dheeravath, V., Busia, D., Rala, A. 2011. Mapping Irrigated Areas of Ghana Using Fusion of $30 \mathrm{~m}$ and $250 \mathrm{~m}$ Resolution Remote-Sensing Data. Remote Sens., 3, pp. 816-835.

Oh, Y., Sarabandi, K., and Ulaby, F.T. 1992. An empirical model and an inversion technique for radar scattering from bare soil surfaces. IEEE Trans. Geosci. Remote Sens., 30, pp. 370 382.

Paloscia, S., Pettinato, S., Santi, E., Notarnicola, C., Pasolli, L., and Reppucci, A. 2013. Soil moisture mapping using Sentinel-1 images: Algorithm and preliminary validation. Int J. Remote Sens., 134, pp. 234-248.

Prévot, L., Champion, I., and Guyot, G. 1993. Estimating surface soil moisture and leaf area index of a wheat canopy using a dual-frequency (C and $\mathrm{X}$ bands) scatterometer. Int. J. Remote Sens., 46, pp. 331-339.

Saux-Picart, S., Ottlé, C., Decharme, B., André, C., Zribi, M., Perrier, A., Coudert, B.; Boulain, N., and Cappelaere, B. 2009. Water and Energy budgets simulation over the Niger super site spatially constrained with remote sensing data. Journal of Hydrology, 375, pp. 287-295.

Thenkabail, P.S., Schull, M., and Turral, H. Ganges and Indus river basin land use/land cover (LULC) and irrigated area mapping using continuous streams of MODIS data. 2004. Remote Sens. Environ., 95, pp. 317-341.

Tomer, S. K., Al Bitar, A., Sekhar, M., Zribi, M., Bandyopadhyay, S., Sreelash, K., Sharma, A. K., Corgne, S., Kerr, Y. 2015. Retrieval and Multi-scale Validation of Soil Moisture from Multi-temporal SAR Data in a Tropical Region. Remote Sens., 7(6), pp. 8128-8153.

Zribi, M., Pardé, M., Boutin, J., Fanise, P., Hauser, D., Dechambre, M., Kerr, Y., Leduc-Leballeur, M., Reverdin, G., Skou, N., Søbjærg, S., Albergel, C., Calvet, J.C., Wigneron, 
J.P., Lopez- Baeza, E., Ruis, A. And Tenerelli, J. 2011a. CAROLS: A New Airborne L-Band Radiometer for Ocean Surface and Land Observations. Sensors, 11(1), pp. 719-742.

Zribi, M., Chahbi, A., Lili Chabaane, Z., Duchemin, B., Baghdadi, N., Amri, R., and Chehbouni, A., 2011b. Soil surface moisture estimation over a semi-arid region using ENVISAT ASAR radar data for soil evaporation evaluation. Hydrol. Earth Syst. Sci., 15, pp. 345-358. 